\title{
Bicha! Futebol e reprodução de masculinidades pelo discurso jurídico da liberdade de expressão
}

\author{
Bicha! Football and reproduction of male for the legal \\ speech of freedom of expression
}

\author{
Jõ̃o Carlos da Cunha Moura \\ Faculdade Laboro
}

Resumo Ressalta-se como as instituições (formais e informais) domesticam para a imposição de ideais performativos de liberdade de expressão e consideram o espaço de domínio político dos discursos de ódio. Nesse sentido, o presente texto investiga de que forma o discurso de liberdade de expressão, constitucionalmente garantido, pode promover ações e enunciações de ódio contra homossexualidades. Tem como hipótese o seguinte: a constituição do ódio nas práticas futebolísticas brasileiras é norteada por um processo de discursividade jurídica e política, as quais docilizam indivíduos em espaços subjetivos cristalizados e espaços físicos localizados para a sua realização concreta.

Palavras-chave: Liberdade DE eXPRessão; Homofobia; Discurso DE Ódio; FutEBOL.

Abstract It shows how institutions (formal and informal ones) domesticate to impose an ideal of performance in order to express freedom speech. In this way, this paper investigates how discourses about constitutional freedom speech may promote actions and enunciations of hate against homosexuals. This is how hypothesis works: constitution of hate in Brazilian football practices is guided for a process of juridical and political discourses, which endorse docile individuals in subjective crystalized spaces. Key-words: Freedom SPeECH; Homophobia; Hate speech; FoOtball. 


\section{INTRODUÇÃo}

O espaço de um jogo de futebol é uma grande teia de representações dos sujeitos que nele se inserem. Evidenciado como um projeto espetacular de certa disputa antagônica entre duas equipes, o futebol reflete muito mais do que o conluio imaginado no campo de jogo.

O futebol oferece uma interminável trama de ações para o desenvolvimento da reprodução de masculinidades já existentes no contexto social. O modo de ser homem, a partir do desempenho no estádio de futebol, não se caracteriza sem antes promover ações próprias da forma masculina na sociedade.

É nessa perspectiva que a ação corporal e linguística, no espaço do futebol, apresenta um processo de interdição de todas as categorias não masculinas (ou não masculinizadas). Nos dias de hoje, no Brasil, os torcedores acionam um signo verbal para definir esse enredo masculino na narrativa do futebol. A palavra "bicha" é gritada no momento de reposição do jogo pela figura do goleiro, com o intuito de criar algum tipo de desqualificação e desequilíbrio emocional que o leve a erro.

Interessante observar, como apresenta-se no texto, que a palavra designada à figura do goleiro não diz respeito à sua sexualidade. A expressão não é utilizada apenas contra aqueles que se identificam como homossexuais, mas a todo e qualquer goleiro, no momento da reposição.

Para estudar o fenômeno, é necessário entender toda a carga ideológica presente no termo, por meio de uma ordem discursiva que define não apenas o sentido da palavra, mas o seu momento de utilização.

Além disso, é necessário fazer visível discurso sob o qual funciona a expressão "bicha", o que lhe garante a reprodução legítima e qual a influência de uma prática jurídica nesse contexto.

Dessa maneira, uma análise do discurso e a ideia da crítica radical ao Direito serão necessárias para a discussão. Parte-se de uma problemática relacionada com a reprodução das masculinidades e do machismo nos diversos espaços da sociedade, tendo como reflexo a expressão "bicha" no campo de futebol. 
Logo, a primeira tarefa é entender o processo de masculinização no contexto do esporte. Depois, procura-se analisar os mecanismos de censura da homossexualidade como antagonista do masculino, no espaço futebolístico. Ao fim, pretende-se discutir o conteúdo jurídico da liberdade de expressão e o seu reflexo na eclosão de uma livre manifestação nos estádios de futebol, revelado que existe uma ideologia da interdição por intermédio da legitimidade jurídica do direito de fala sobre a homossexualidade.

Deve-se transgredir a forma de análise catalogada na dialética sujeito-objeto, passando-se a se analisar o objeto a partir dos sujeitos, criando uma fórmula que pode ser representada em sujeito-objeto-sujeito: um sujeito que analisa um objeto sob a ótica de outros sujeitos. Assim sendo, aborda-se o método dialético em uma dimensão crítica conforme aquela que se deve adotar na filosofia radical.

Por conta da extensa profundidade que o tema propõe, as análises históricas, sociais, políticas e jurídicas devem ser levadas em consideração para a formulação de mudança radical sobre a ideologia machista. Principalmente porque elas levam o sujeito a pensar de determinada maneira, a ponto de enunciar materialmente seus preconceitos e intolerâncias ao patamar de "opinião" e "expressão", categorias próprias de um espaço de liberdade de fala. Nessa perspectiva, a análise não pode se furtar de pensar o tempo presente do qual se extraem essas formas.

\section{A REPROdUÇÃo do MASCULINO NO FUTEBoL}

A virilidade do homem na reprodução do discurso sobre as masculinidades é o reflexo de uma série de práticas sociais evidentes em diversos quadros sociais. No espaço do futebol, essa forma discursiva é bastante observada nas disputas esportivas que demandam força e habilidade direcionadas para a criação de duas figuras: o jogador e o torcedor. Ambas devem permanecer calcadas em um aspecto de representação da masculinidade a qual o homem deve adequar-se.

O campo de jogo, o estádio de futebol, é o espaço espetacular de desempenho desses papéis, possuindo estruturas rígidas em seus gru- 
pos. Isso diz respeito a uma atuação de papéis oriundos de exercícios de manutenção do poder. É por esse desempenho que se criam as regras formais de participação no espetáculo do futebol, "uma espécie de permissão que autoriza a representação cênica de uma ou mais fatias de vida, pública ou privada" (VANEIGEM, 2016, p. 182).

O futebol transita em ambos os espaços público e privado. É público no sentido de pertencer a um aspecto cultural, reproduzido pela sociedade brasileira como um discurso, mas também como prática esportiva; e privado, pois existe a possibilidade de manifestar individualmente de qual lado do jogo esportivo se quer estar. Soares (1999) explica que essa manifestação do futebol em âmbito tão amplo reflete um campo privilegiado de atenção descontínua, deixa de ser um hobby temporário, esporádico e se torna uma prática cultural. O futebol institucionaliza-se.

Entende-se por espaço público não apenas aqueles nos quais todas as pessoas tenham acesso, mas, de acordo com Goffman (2010), aqueles espaços nos quais existe contato entre as pessoas e que estão para além do contato familiar, no sentido de privacidade das relações. $\mathrm{O}$ âmbito privado é evidenciado no grau de apoio a um clube de futebol, o qual também é parte de uma iniciação no mundo privado da masculinidade: o clube que se escolhe ou se é levado a escolher por influência da família, círculo de amizades etc., representa uma catequização na formação do indivíduo.

Além disso, existem ambientes sociais cujos espaços são restritos para que certos grupos se façam presentes, nesse caso, isso acontece para envolver "um esforço para evitar a penetração de fronteiras de ego, a contaminação por indesejáveis e ataques físicos" (GOFFMAN, 2010, p. 20).

A função social do futebol é bastante discutida pelos estudiosos da sociologia do desporto, mas isso não significa que ele deixa de ser uma representação da masculinidade das sociedades industriais. Isso se define pela coincidência no que se refere às atividades de lazer desempenhadas nessas sociedades. Existe, por sua vez e ao mesmo tempo, um ato político em cada atividade desportiva. $\mathrm{O}$ futebol não deixa de cumprir esse ciclo. 
Transforma-se em lazer para as massas industriais, as quais exigem do ator no espetáculo à presença virilidade (representadas na força, atitude, proatividade), ao mesmo tempo em que esse ator demanda vibração e excitação dos espectadores (DUNNING; ELIAS, 1992).

O futebol no Brasil está carregado de valores sociais que fazem com que este esporte esteja apto a integrar amplas parcelas da sociedade brasileira, via identificação nacional. Trata-se de um fenômeno social onde uma grande parte da população brasileira, sobretudo masculina, pratique e/ou assista regularmente partidas de futebol. Isto pois, além de ser um esporte que pode ser praticado (precariamente) com o mínimo de condições materiais, o futebol goza de um tratamento privilegiado por parte dos meios de comunicação de massa, o que faz com que ele seja praticado e assistido em todo país, tornando-se uma das principais manifestações coletivas do país (SOUZA, 1996, p. 114).

De acordo com Dunning (1992), explicar o futebol pela divisão dos sexos atribui-se pela dinâmica masculina nesse espaço. Isso tem como efeito a consolidação da hegemonia masculina nos campos do futebol. Seja entre os jogadores ou entre os torcedores, o exercício masculino deve excluir toda e qualquer prática que se perceba e se mostre desviante.

Assim, internamente, os grupos que se apresentam no espetáculo do futebol seguem um perfil de ostentação e celebração da sua masculinidade. É com essa forma "homem" que podem fazer frente tanto no estádio em confronto com o adversário como ser percebido pela sociedade. $\mathrm{O}$ agir expresso desse modo é comumente simulado nas manifestações coletivas, como se observa em cânticos popularmente disseminados com intuito de insulto. Entoados pelos torcedores e jogadores, essas rimas e gritos chamam a atenção para a colocação do sujeito homem adversário em um espaço sem masculinidade (SOUZA, 1996).

No sentido apresentado, o espetáculo como acúmulo daquilo que se pode desempenhar como força contra antagonismos que se criam 
para a legitimidade dos discursos. Esse antagonismo é necessariamente binário, de modo a confirmar a existência do poder, e dele apropriar-se. Por conta do espetáculo, os conflitos entre lados opostos podem ser evidenciados como reivindicações individuais, conforme afirma Vaneigem (2016). No futebol, isso toma forma na reivindicação de ser homem, contra o antagonista não homem, o qual pode ser representado pela feminilidade, homossexualidade ou características não masculinas para o jogo propriamente dito, no qual a disputa de longe é a vitória na partida, mas a representação daquele grupo como o mais viril.

O poder precisa ser visível, no sentido de aparecer para todos, seja no próprio grupo, seja na representação para o adversário e para o restante da sociedade. Mostrar-se descontínuo é fazer que o poder do grupo não seja percebido. As subjetividades nesse aspecto tomam um espaço central na forma espetacular, subdividida pelas hierarquias do poder. Homologadas pelas normas estabelecidas pelo poder. "O subjetivo adquire as formas objetivas dos estereótipos por meio da identificação. Nesse processo ele tem de ser repartido em fragmentos absolutizados e reduzido de forma ridícula [...] Ser é possuir representações de poder" (VANEIGEM, 2016, p. 182).

Interessante notar que essas representações fixam-se ao longo do tempo, cada uma de uma forma específica. Os códigos e até a territorialidade não são permanentes, isso depende sempre em qual ambiente os atores estão embrenhando para o confronto espetacular do jogo de futebol. Nessa esteira, uma atitude de um sujeito "homem" é evitar o confronto físico, por exemplo, ato esse que deve ser devidamente acionado em outro espaço, como os jogos "em casa" (aqueles que se dão no próprio estádio ou sede no qual o clube e os torcedores têm contato direto e sensação de pertencimento).

Onde existem estas regras de exclusão fica claro que a mera presença do indivíduo, independentemente de sua conduta enquanto presente, comunica ou que ele possui as qualificações necessárias para a entrada ou que ele está se comportando inapropriadamente. Aqui encontramos um motivo para ou se querer entrar num 
lugar em particular ou para não se querer ser visto nele (GOFFMAN, 2010, p. 21).

Foucault (1988) afirma que a sexualidade nunca foi reprimida, ela é a cada tempo um dispositivo que precisa ser visível, pois é isso que garante a hierarquização das condutas. São as relações de poder, ainda de acordo com Foucault, que imperam na determinação da vida que cada uma das pessoas vive; o poder é ditado por uma espécie de lei que age de forma negativa no exercício da sexualidade. Confirma, nesse caso, a subdivisão explicitada por Vaneigem (2016) na construção objetiva das subjetividades. Para Foucault (1988), além disso, é essa hierarquização que determina o maniqueísmo do permitido e do proibido; o sexo é determinado pelo que a lei sexual investe como regra. Por conta disso, as sexualidades estão marginalizadas em espaços de exclusão, elas podem existir, porém não aparecer, exceto nos campos que lhes são determinados: a sexualidade não é reprimida, mas interditada, unificada pela não manifestação, pela inexistência e pelo mutismo. O que é em aparência contraditório nessa unificação é, na verdade, a injunção própria das relações que se aplicam sobre sexualidade. Assim, a relação unitária do poder e do sexo é correspondida nas mesmas instâncias do direito, o instrumento de relação social que interdita as condutas hierarquicamente (do Estado à família, do judiciário às punições populares), fazendo subsunção ato transgressor e punição: o jogo entre o lícito e o ilícito.

Há uma ação corporal no suporte ao time. Nesse caso, põe-se o corpo nesse desempenho que vai da ida ao campo até o ato de torcer nas condições mais diversas que se apresentam (chuva torrencial, sol a pino, viagens longas para participar dos jogos, estádios sem infraestrutura etc.). É interessante notar que, mesmo as lutas físicas promovidas tendo como pano de fundo o futebol, a capacidade masculina está presente não apenas na possibilidade de vitória na luta, como também na resistência aos golpes que porventura lhes serão atingidos. De acordo com Alabarces et. al. (2008), tudo leva à configuração de uma ação do corpo.

Assim, é notável que o corpo de quem emite discursos está para além das palavras ditas, isso tem por sentido a exposição à vulnerabili- 
dade da qualidade daquele outro que não pertence (ou não se quer deixar pertencer) ao espaço realizado. O corpo é o instrumento da violência discursiva, uma vez que apenas pelo corpo se fala, para além, o próprio corpo fala. Do silêncio à fala, o corpo expressa muito mais do que aquilo que se diz em mera linguagem de sons e escrita (BUTLER, 1997).

No espaço futebolístico, essa sexualidade é interditada de maneira a sobrepujar os transgressores, exercendo a punição pela palavra, pelo dito. As expressões refletem essa interdição do e no espaço do futebol. A discordância com a decisão arbitral imediata, o erro em certa finalização, a derrota no jogo propriamente dito ou nas disputas simbólicas das canções, além do revés na disputa física, são maneiras de fazer aparecer o conteúdo não masculino dos agentes adversários.

A caracterização entre machos e "bichas" abre espaço para práticas e discursos que buscam a distinção. Isso expõe a linguagem da subordinação. O homem é assim porque em uma disputa simbólica pode roubar os atributos masculinos de seus antagonistas. A dominação expressa-se em uma espécie de retórica de luta corporal. A extensão simbólica da violência compõe a subordinação de todos os outros, ordenando uma estrutura hierárquica, à figura do homem (SEGATO, 2003).

É uma questão estratégica, uma vez que nesse sentido a própria palavra ou a agressão física mostram a punição, fazem-na aparecer de maneira dramática: imagina-se a situação, provoca-se o conflito de modo a confirmar a necessidade de punir - o poder não pode ser cínico, ele precisa manifestar-se, para que aqueles que o utilizam na forma punitiva apareçam como legítimos, ou seja, não estejam no locus específico do punido. O poder exercido dessa forma oculta a falta da masculinidade de quem age violentamente.

Razão geral e tática que parece se impor por se mesma: é somente mascarando uma parte importante de mesmo que o poder é tolerável. Seu sucesso está na proporção daquilo que consegue ocular dentre seus mecanismos. O poder seria aceito se fosse inteiramente cínico? O segredo, para ele, não da ordem do abuso; é indispensável ao seu funcionamento. E não somente porque o impõe 
aos que sujeita como, também, talvez por que lhes é, na mesma medida, indispensável: aceitá-lo-iam, se só vissem nele um simples limite oposto a seus desejos, deixando uma parte intacta, mesmo reduzida - de liberdade? O poder, como puro limite traçado à liberdade, pelo menos em nossa sociedade, é a forma geral de sua aceitabilidade (FOUCAULT, 1988, p. 83).

O que se percebe, até pela forma de disputa das partidas, é que quem intente jogar ou participar do espaço do futebol deve mostrar uma maneira idiossincrática de se perceber como ator do espetáculo, desempenhando um papel de força e agilidade, características masculinas levadas a todas as instâncias do futebol. É como se o futebol fosse biologicamente masculino. Independe de quem o pratica (no sentido de prática esportiva ou apoio ao time), as ações são masculinizadas. Se é possível fazer um paralelo, até pouco tempo na história das escritas homem e humanidade eram semanticamente idênticos; desmasculinizar um indivíduo é ao mesmo tempo desumanizá-lo, o que o torna uma vida não necessária, dispensável. Agamben (2010) nota essa dispensabilidade da vida quando percebe que as formas de extermínio se ampliam no pós Segunda Guerra, o campo de concentração toma outras formas, até mais abstratas. O campo de concentração deixa de ser a concretude do extermínio para ser a sua justificação: se existe o campo é porque alguém precisa ser exterminado.

A ideologia dos séculos XX e XXI pauta-se bastante na ideia de redefinir as vidas privadas. Uma vez que essas começam a aparecer no âmbito público, as vidas necessitam de um novo molde, de novos desenhos institucionais para que se identifique quais vidas podem cumprir um papel útil para todo o restante da sociedade. Assim, é característica a descontinuidade entre homem e cidadão, sujeito e qualidade (AGAMBEN, 2010).

O sujeito odiado é aquele que, para além de estar inserido ou excluído, dentro ou fora, é irrepresentável; não constitui tipo algum de representação. Isto é, para o espaço do futebol, no espetáculo com todos os papéis determinados por um poder repartido, o homossexual 
é a falta de representação do masculino, sua não representação no estádio de futebol.

O que se depreende disso é que o espaço da disputa futebolística é a ampliação do campo de concentração, no qual precisa-se estimular o extermínio das figuras não masculinas. Interessante notar, com Foucault (1988), que as relações de poder não se dão inconscientemente, elas estão o tempo todo intrinsecamente ligadas. São sempre, e a todo momento, realizações de ações e reações, as quais estão prontas para determinar toda sorte de enquadramentos, homogenizações, redistribuições.

[...] as relações de poder são, ao mesmo tempo, intencionais e não subjetivas. Se, de fato, são inteligíveis, não é porque sejam efeito, em termos de causalidade, de uma outra instância que as explique, mas por atravessadas de fora a fora por um cálculo: não há poder que se exerça sem uma série de miras e objetivos. Mas isso não quer dizer que resulte da escolha ou da decisão de um sujeito, individualmente (FOUCAULT, 1988, p. 90).

O pertencimento pela masculinidade é essencial para o desenvolvimento das atividades no jogo de futebol. Do senso estético (músculos, corpo forte) às formas de atuar em sociedade (honradez, domínio), o masculino se faz pertencer em espaços de reprodução cobertos por signos de representação do homem, sendo sempre um movimento de sociabilidade com relação a outros gêneros. O homem passa a ser a medida do gênero. Na falta de tudo, é-se mulher, na presença de alguns atributos, sem contudo ser mulher é-se homossexual. O cotidiano masculino e os seus espaços devem ser respeitados, mostrando que estes não podem ser adentrados por qualquer pessoa. Só pertence ao espaço masculino quem dispõe o próprio corpo para a prática de ser homem (CECCHETTO, 2004).

...os meios de comunicação procuram "mostrar ao grande público que o futebol, 'esporte de macho', é uma instituição séria, com uma moral rigorosa. O jogador 
é sempre mostrado com seus familiares, no seu dia-a-dia, para que haja identificação da parte do torcedor" (SAMPAIO, 1985, p. 66).

A sociabilidade masculina no Brasil é atravessada pelo discurso esportivo. As ferramentas ideológicas presentes no espetáculo esportivo são o que determinam o espaço do homem. De acordo com Gastaldo (2005), os desempenhos masculinos, os quais ocorrem em vários espaços determinados (estádios, bares etc.) revelam uma lógica cotidiana de uma cultura extremamente masculina no Brasil.

Para confirmar a ideia de hombridade, ou de masculinidade fixa e permanente, existe a garantia de que não haverá mudança de posicionamento e de suporte ao time, mesmo que haja um revés considerado humilhante. Um princípio de fidelidade é mais valorado quando emitido para o clube do que quando é direcionado para as relações íntimas e sociais.

O futebol é um desses ritos de iniciação do pertencimento ao masculino. O campo de futebol é, em todos os aspectos, um espaço masculino. Das brincadeiras infantis ao campo propriamente dito, o menino é socializado com base no futebol (GUEDES, 1982).

No espetáculo do jogo de futebol, por exemplo, as figuras femininas das torcedoras à beira do campo de jogo (como uma referência às cheerleaders norte-americanas) são objetificadas para que o homem busque representar sua masculinidade nas mulheres ali presentes.

No futebol representação da sociedade e seus problemas de gênero, na relação entre homens, é comum a busca da vitória física, ou simbólica de um homem sobre o outro, o que não acontece com as mulheres ou homossexuais, às quais outras práticas desportivas são direcionadas.

Por exemplo, os árbitros de futebol são as figuras mais desprezadas pelo público, que constantemente atribui-lhes o rótulo de homossexuais, dado que a sua posição no espetáculo é dotada de uma ambiguidade: o árbitro está entre público assistente e jogador. De fato, o árbitro participa e interfere nas partidas, mas não as joga, sendo seu corpo considerado zona neutra, necessitando, 
por isso, ser decidido, e possuir "personalidade". Os árbitros são também os únicos personagens do futebol que possuem uma outra carreira profissional paralela. Eles também são diferencialmente identificados pelo uniforme, que é quase um traje civil, destacando-se dos padronizados uniformes dos jogadores. Por tudo isto, qualquer desvio de sua conduta é prontamente taxado de manifestação feminilizante, homossexual, ou então de desvio de caráter (SOUZA, 1996, p. 146).

Ser homossexual, nesse sentido, independe de prática sexual propriamente dita, da relação sexual em si. Tem muito mais a ver com a questão do seu posicionamento político como sujeito na sociedade. Nesse sentido, Mott (2000) aponta que a homossexualidade tem uma razão de ser, de existir. É assim que o indivíduo quer ser visibilizado na sociedade, como sujeito político que pode participar dos atos da vida política e não como alguém que precisa apenas do reconhecimento jurídico-político.

\section{O CLANDESTINO HOMOSSEXUAL NO FUTEBOL}

A sexualidade em si mesma não é preocupação de quem a estuda, interessa mais saber o que se diz sobre ela. A homossexualidade no espaço físico do futebol tem a ver com questões acerca do discurso que se quer manter como técnica de reprodução do masculino como aporte necessário para se participar do espetáculo. Assim, um discurso que se quer afastar do campo de futebol é o de que a homossexualidade pode fazer parte de um conteúdo pertencente ao espaço.

Foucault entende que não se questiona no espaço político por quem o indivíduo se interessa em sentido sexual, mas pelo controle desses desejos. É como se perguntasse "és um escravo ou o mestre dos teus desejos?” (FOUCAULT, 1982, p. 235). O sexo se transforma em problema moral não pela qualidade do desejo, mas pela quantidade.

Nesse ponto, o homossexual toma a forma de um elemento subjetivo que não controla o desejo, pois o sente na mesma medida da 
antagônica parte do homem: a mulher. É como se o homem, enquanto indivíduo, se igualasse à mulher no espaço do desejo sexual. Que o estado homossexual não está mais adequado a um indivíduo, mas a um conjunto de sujeitos que, muitas vezes, não são homossexuais (FOUCAULT, 1982).

Como o futebol transita entre o público e o privado, isso significa dizer que as representações no espetáculo precisam estar definidas objetivamente. O homossexual é a não expressão do heterossexual, ou seja, é aquilo que se diz sobre o não ser do heterossexual. Deste ponto de vista, a sexualidade censurada é aquela que precisa estar inserida em um âmbito oculto das reproduções públicas. Para Prado e Machado (2008), é um jogo político que expressa limites para a aparência pública de cada um dos sujeitos. Assim, ser homossexual é representar no espaço público aquilo que só poderia ser mostrado em espaço privado.

A formação regular do discurso pode integrar, sob certas condições e até certo ponto, os procedimento do controle (é o que se passa, por exemplo, quando uma disciplina toma forma e estatuto de discurso científico); e, inversamente, as figuras do controle podem tomar corpo no interior de uma formação discursiva [...]: de sorte que toda tarefa crítica, pondo em questão as instâncias do controle, deve analisar ao mesmo tempo as regularidades discursivas através das quais elas se formam; e toda descrição genealógica deve levar em conta os limites que interferem nas formações reais (FOUCAULT, 1996, p. 66).

No que tange ao contexto especial da partida de futebol, o sujeito homossexual é tudo aquilo que representa a falha da institucionalização do masculino. O consenso sobre a hegemonia do homem no futebol estende-se à participação dos sujeitos que se inserem nesse espaço. De qualquer forma, o que torna a homossexualidade alvo da ofensa no espaço do futebol é a extensão pública de características não masculinas em um espaço definitivamente masculino. 
O preconceito é um sentimento e um pensamento de simplificação da complexidade que se manifesta no outro. Assim, algumas diferenças assumem concretamente o caráter de desigualdades e algumas desigualdades, o lugar de diferenciações. O sistema de pensamento e ação que torna esta passagem da diferenciação para a desigualdade incomunicável e não nomeável se chama preconceito social (PRADO; MACHADO, 2008, p. 25).

Para além da sexualidade em si mesma, a discussão é sobre uma moral, ou até mesmo sobre a própria moral. Atos e códigos morais se diferenciam no momento em que os primeiros são a representação dos últimos (FOUCAULT, 1982). O código moral não determina o que se deve fazer, mas o contrário: a regra estabelecida é justamente o conteúdo do desvio. No futebol o código moral determina o desvio do masculino e não a mera masculinidade.

Existe um projeto de invisibilidade das práticas homossexuais. Nem os espaços mais masculinos fazem-na desaparecer, ela precisa existir o tempo todo, pois ela também fundamenta a existência do sujeito masculino, de acordo com Foucault (1988). Importa dizer que as homossexualidades existem como possibilidades de normalização simbólica, na medida em que sua instituição como diferenciação de classe só permite uma comparação de exclusão (LACLAU, 2005).

É pela apresentação do discurso de exclusão que se faz, ao mesmo tempo, aparecer e desaparecer a figura do homossexual no futebol. Se o futebol é "coisa para homem", não é porque nele só se insere o sujeito masculino, mas porque nele estão as características desse sujeito. Como Foucault (2008) afirma, o sujeito é um espaço que necessita de preenchimento com certas especificidades.

No campo de jogo, o homossexual é um indivíduo que está determinado à passividade, o que lhe transforma em antagonista no campo de jogo. A economia das sexualidades no futebol é a reprodução daquilo que se quer mostrar no espaço público. Ainda mais em um espaço que se mostra para espaços externos à ideia de nação, isto é, são disseminados para outros países. Para Cornnell (2007), a masculinidade e a glo- 
balização têm uma enorme importância na reprodução dos conteúdos machistas, impregnados de valores e interesses neoliberais.

Como a nação é representada no futebol como uma irmandade passional, ela é obrigada, para encontrar a si mesma, a distinguir sua própria homossociabilidade da mais explicitamente sexualizada relação entre homens, o que requer a identificação, o isolamento e a contensão do homossexualismo (sic) masculino (SOUZA, 1996, p. 146).

Como já afirmou-se, a homossexualidade não deve ser escondida, nem censurada, mas mostrada. O que define essa aparição é o discurso que se tem acerca da homossexualidade. A manifestação sobre ela é justamente aquilo que lhe torna invisível. Nesse sentido, expressar-se a respeito da homossexualidade no espaço do futebol é determinar a substância explícita de uma série de práticas sociais que determinam o sujeito.

Quem foge do campo de batalha rechaçando o encontro corpo a corpo, aquele que teme o "mano a mano", aquele que não tem amor pelo time é definido como "bicha”. O homem se caracteriza por ter certos atributos: "colhões", força física, valentia, coragem. As "bichas", não machos, se caracterizam pela carência dessas características. [...] No plano dos discursos, nos cânticos e narrativas, a masculinidade está associada ao ativo e o feminino ao passivo. Ativo e passivo se referem aos papéis sexuais (ALABARCES et al., 2008, p. 119-120).

Existem, nesse aspecto, duas categorias que podem reproduzir a masculinidade no espetáculo do futebol. Uma delas é a categoria jurídica da liberdade de manifestação, aquela determinada como uma espécie de liberdade para expressar de forma clara tudo aquilo que o indivíduo pretende. Outra categoria é a manifesta censura às práticas não masculinas no espaço do espetáculo do jogo de futebol. O desempenho de papéis, aí imposto, tem como função a produção da masculinidade pela negação da homossexualidade. 


\section{O DIREITO EM FALA: SOBRE BICHAS E HOMENS}

Atualmente, no Brasil, é bem comum a utilização da expressão "bicha" no momento em que o goleiro tem a função do recomeçar da partida de futebol. De acordo com os espectadores, em geral, o termo é gritado pela massa como um modo de desestabilizar a concentração do goleiro na citada reposição. Importa ressaltar que a figura do goleiro é representada de forma ambígua.

Não há um marco inicial determinando quando essa prática se inicia no Brasil, mas sabe-se que ela não é exclusiva. No México é prática comum que as torcidas, nas mesmas circunstâncias de reposição do goleiro, emitam o termo "puto", o qual tem conotação similar ao termo "bicha", utilizado nos estádios brasileiros. Na Argentina, e outros países da América Latina, o termo "puto" também é usado no sentido de desqualificar a masculinidade do jogador ou "hincha" (torcedor) rival (PONS, 2014; ALABARCES et al., 2008).

De acordo com SOUZA (1996), o fato de poder utilizar tanto as mãos quanto os pés dá ao goleiro a intermitência da masculinidade para a homossexualidade. Por conta desses privilégios da regra, o goleiro muitas vezes é responsabilizado exclusivamente pelas derrotas de sua equipe, algo que o coloca em uma espécie de identificação externa à sua pessoa: se não toma gols, pode ser considerado o grande homem do jogo, se sofre os gols, pode ser indiferente ou alocado em locus de homossexualidade.

Portanto, o grito de "bicha", exprimido contra o goleiro no sentido da sua desestabilidade psicológica (errar a reposição, por exemplo), tende a carregar de sentido a palavra enunciada. Foucault (1996, 1999, 2008) afirma que as palavras já têm sua carga ideológica representada. Em certo sentido, pode ser que a expressão não tenha a conotação ofensiva para certas pessoas, mas para a ideologia dominante revela muito mais do que o expresso.

Dessa maneira, a expressão "bicha" é carregada de sentido, uma vez que manifesta uma das formas de dar sentido de passividade e indiferença à figura representada no campo. Experimento de toda essa falta 
de masculinidade, a expressão torna-se a reprodução de um discurso do que se diz sobre a homossexualidade.

Para Foucault (1996), essa repetição por meio da palavra é a reprodução do não dito no enunciado em si mesmo. A palavra é reutilizada com sentido múltiplo, para que se legitime sua descontinuidade semântica, dando riqueza cumulativa de sentido. Isso quer dizer que a expressão "bicha" para a homossexualidade já tem uma série de sentidos, fundando uma série de possibilidades de fala. Essa posição de fala ainda é determinada pelo autor, não necessariamente um indivíduo unitário, mas que pode ser refletido em um grupo de pessoas que podem expressar a materialidade discursiva.

O autor, não entendido é claro, como o indivíduo falante que pronunciou ou escreveu um texto, mas o autor como princípio de um agrupamento do discurso, como unidade e origem de suas significações, como foco de sua coerência (FOUCAULT, 1996, p. 26).

Goffman (2010) alerta para o fato de que comportamentos em locais públicos, na maioria das vezes, transmitem mais do que uma representação de imposição de regras. Em geral, é possível perceber que certos locais podem ser espaços de colapso da ordem pública, os atos nele praticados, por mais nefastos que sejam, perdem a sua impropriedade (no sentido de serem impróprios), sendo até legitimados em alguns casos.

No espaço do campo de futebol, há um lugar que maximiza o desempenho masculino, minimizando o valor do preconceito de gênero emitido na palavra "bicha".

Como existe uma possibilidade da visibilidade homossexual no espaço do futebol, é necessário que essa tentativa de conquista de um status seja recebida com o máximo de obstáculos em um espaço necessariamente masculino. O preconceito contra homossexuais no futebol revela mais do que apenas o afastamento da subjetividade sexual indesejada, ou o seu aparecimento espontâneo de certo tempo até hoje. 
Como informam Prado; Machado (2012, p. 31): “estes personagens já existem há bastante tempo, mas apenas hoje podem ser vistos".

Essa visibilidade é dada em um duplo sentido: por um lado, afirma-se sua existência pelos gritos das torcidas, por outro, a própria visibilidade é censurada para que aqueles que andam no espaço público sejam coagidos a atuar conforme normas socioculturais de gênero.

A liberdade de manifestação como um direito garante o protocolo rudimentar do preconceito. Pelo discurso jurídico da liberdade de expressão, o sujeito pode exprimir tudo o que lhe existe de conteúdo de pensamento. O sentido da liberdade em si mesma é a falta de coação, podendo adequar-se a uma escolha a ser exercitada em cada momento e situação, espacial ou temporal, na qual um indivíduo ou grupo de indivíduos podem autodefinir-se (CASTRO; FREITAS, 2013).

O espaço do campo de futebol reproduz isso de maneira bastante prática: a autoafirmação masculina é ordenada pela censura à prática homossexual. A expressão "bicha" é emitida como parte do glossário jurídico que é discursivamente planejada pela dignidade da pessoa, da liberdade. Se falta liberdade para exprimir, falta a dignidade humana, que fundamentaria um direito à autodeterminação, reconhecidamente emitido pelo Estado desde o texto constitucional.

Ocorre que o grito emitido, no espaço da determinação individual ou coletiva, é ampliado em um coro de desvalorização da homossexualidade. $\mathrm{O}$ dano, nesse caso, não é meramente à figura do goleiro a ser desestabilizado, mas a toda e qualquer identificação do homossexual. $\mathrm{O}$ ato torna-se difuso, afetando a classe, grupo, coletividade à qual o sujeito homossexual pertence.

Waldron (2010) afirma que, nesse caso, o uso jurídico da ofensa tem por objetivo a humilhação não apenas do indivíduo acuado, mas de todos que possam desempenhar esse papel no contexto político e social. Fazendo a própria vítima assimilar a condição de submissão, buscando atuar de maneira que sua característica não masculina seja oculta e limitando sua participação política.

Foucault (2008), nesse sentido, afirma que o discurso não é um dado existente por si mesmo, mas o efeito de uma série de práticas (ou 
de uma prática discursiva), que podem ser precisadas pela sua aparição. Assim, o cântico "bicha" é uma operação expressiva da liberdade de expressão manifestada no estádio de futebol, nessa operação o grupo de torcedores se envolve na formulação de uma ideia, uma imagem (a do homossexual), produzindo uma prática discursiva, esse "conjunto de regras anônimas, históricas, sempre determinadas no tempo e no espaço, que definiram, em cada época e para uma determinada área social [...] as condições da função enunciativa" (FOUCAULT, 2008, p. 133).

O grito, o qual tem alvo a desestabilidade emocional dos goleiros, refere-se a uma economia das relações sociais, que lançam um conteúdo de direito de livre manifestação para emitir e expressar o ódio contra os homossexuais em determinado espaço político, inserido esses sujeitos na ordem do discurso.

É nesse momento que se percebe uma contraditória combinação de antagonismo e compatibilidade entre os torcedores adversários no espetáculo do futebol. O comportamento é perceptivelmente analisado do ponto de vista da masculinidade e afastamento da homossexualidade. O que parece repetir um discurso de brincadeiras entre os participantes do enredo futebolístico, as torcidas podem estar unidas pelo aspecto de compatibilidade e antagonismo entre si: não importa o lado adversário, mas sim sua rejeição à homossexualidade; ao mesmo tempo em que empurram para o outro lado da competição a subjetividade não masculina.

O espaço é determinado. Não se pode falar sobre a homossexualidade, ou dela se usar para ofender, em qualquer lugar. $\mathrm{O}$ que interessa nos usos das relações jurídicas de poder é atuar, de momentos em momentos, de forma política. Assim sendo, na expressão "bicha" há um conjunto de coisas ditas e não ditas, isto é, um artefato semântico suscetível de significação. É um domínio no qual "certas figuras e certos entrecruzamentos indicam o lugar singular de um sujeito falante" (FOUCAULT, 2008, p. 139).

O discurso ultrapassa aquele momento do "dito" e do "não dito", mas é parte de um processo contextual e histórico. O ato linguístico de injúria age como violência física, através de um efeito simbólico. $\mathrm{O}$ discurso que se dirige pode dar a ideia do que pode ocorrer com o 
indivíduo afetado no futuro. É um reconhecimento que não pressupõe seu próprio reconhecimento, pois irrepresentável: o reconhecido, mas não pode ser reconhecível. A linguagem é uma ferramenta tão opressora quanto a violência que ela representa, pois é a própria ferramenta (BUTLER, 1997).

Dito de outra forma, o discurso emitido nesse momento é o de descaracterizar a subjetividade homossexual do ponto de vista da sua notabilidade no campo de jogo. É a possibilidade de fazer aparecer, sem ser visto; de jogar, sem disputar; de pontuar sua existência, sem, no entanto, existir enquanto tal.

Como Goffman (2010) aduz, é a possibilidade de estabelecer como parte da comunidade. É como o membro de certas coletividades (movimentos políticos, entidades profissionais, comunidades locais etc.) deve se manifestar para ter acesso aos seus conteúdos, bem como para afastar conteúdos daquelas que lhe são "rivais".

No modelo liberal jurídico a ideia de liberdade é confrontada com o próprio discurso. É que, de acordo com Vainegem (2016), a liberdade do liberalismo não passa de um sistema de controle das liberdades consideradas marginais. Assim, o que se transfere em sede discursiva como um adorno de formas de agir transforma-se no seu próprio aprisionamento. Ao fim, a ideia de que as liberdades individuais têm limite na liberdade de cada um, isto é, a liberdade de um começaria onde termina a liberdade do outro, reforça a sua interferência mútua. Ao passo que há negação desta máxima, indivíduos perdem sua participação política; no momento em que se aceita a limitação, sua personalidade jurídica perde forma.

É pelo sentido do que Hall (2003) chamou de código que um signo já instituído é potencialmente transformado em um discurso. Pelo caráter dominante das formações discursivas, em uma ordem cultural também dominante, os signos são remetidos a um mapa de realidade social, carregado de sentidos. Tal ordem é fomentada por uma série de significados, práticas e usos, além de uma teia de poder que é emaranhada por ideologias.

A linguagem é também um meio de demonstrar dominação e força. Nesse sentido, é utilizada para relegitimar as relações de um poder 
já ordenado, organizado. Na medida em que se tem legitimidade nas relações de poder, a linguagem é também ferramenta ideológica (WODAK, 2003).

Com isso, a expressão "bicha", utilizada de forma livre em um espaço público, com conteúdo jurídico, garante que o homossexual tenha sua participação política limitada no sentido de questionar a utilização da palavra enquanto forma de censura à sexualidade e também, concomitantemente, é despersonalizado juridicamente quando tenta deslegitimar um conteúdo carregado de discurso jurídico (de liberdade de expressão). De um lado, produz-se liberdade, no sentido de garantir participação política, de outro, consome-se liberdade, para que se tenha em mãos o direito de uso da liberdade de expressão.

Ainda, de acordo com Raoul Vaneigem, o poder que se instala nessas relações é um poder que garante que todos aqueles que se adequem ao papel a ser desempenhado ganhem "honras" sendo "privilegiados para odiar” (2016, p. 219). No campo de futebol, sustenta-se uma ambição desiludida, garantindo que possam propagar ódio com todas as formas políticas e jurídicas dispostas na sociedade liberal.

Nessa perspectiva, o próprio sistema jurídico cria sua armadilha de autosujeição do indivíduo. Cria uma espécie de enquadramento necessário, o qual precisa ser utilizado pelos sujeitos do espaço determinado e rompido por aqueles que o querem adentrar. $\mathrm{O}$ resultado é a alocação de todos em uma localização de normalidade, como é o espaço do campo de futebol.

O Direito, na perspectiva da limitação, não apenas legitima como incentiva a prática preconceituosa. $\mathrm{O}$ ato que é aparentemente transgressor no grito "bicha", é uma vertente de inserção na lei. Não existe culpa na emissão do conteúdo linguístico, pois não se refere a uma violação, isto é, o código significativo é apresentado. É por isso que Agamben (2010) afirma que o Direito não tem vigência, salvo naquilo que consegue capturar dentro de seu conteúdo. Essa captura, no entanto, não significa que exista uma proteção jurídica, mas ao contrário: o Direito captura as vidas para abandoná-las. Ninguém estaria fora da lei, mas abandonado por ela; não se está nem fora nem dentro. 
No caso da homossexualidade, esse abandono se reveste na figura de todos os significativos linguísticos legitimados juridicamente em nome de uma liberdade de expressão, ou de um direito de livre manifestação. "Bicha", nesse caso, não é colocado fora da lei, mas abandonado por ela, exposto no risco de um limite em que a sua própria vida (vista no espaço público) e o Direito (aquilo que lhe invisibiliza) coincidem.

É por isso que homossexuais não têm um direito de falar sobre si, uma vez que são produto daquilo que se diz de sua personalidade, subjetividade ou qualquer aspecto individual. O direito de fala é uma ordem jurídica que separa a licitude do ser e a sua ilegalidade. Quem tem um direito de fala sobre a homossexualidade, para Foucault (1988), são os sujeitos que dela podem se utilizar para criar uma rede de penetração nos corpos cada vez mais detalhada para uso no controle populacional cada vez mais extenso. Não se julga a sexualidade, ela é administrada.

No futebol, essa administração é percebida no teor linguístico da expressão "bicha". Simbolicamente o conteúdo da palavra é o exercício administrativo de vida e morte do homossexual, representado pelo pertencimento ou não do sujeito homossexual no espetáculo do futebol.

Existe, nesse ponto, uma importância cada vez mais ampliada do sistema jurídico, sob a forma da lei. No mesmo intento, a lei só pode agir de forma violenta, pois ela é instrumento de dominação, já que ela não pode ser transgredida. Nesse sentido, a lei nunca é transgredida, pois age tanto simbolicamente quanto violentamente. $\mathrm{O}$ que a lei cria é o seu funcionamento como normalidade: normaliza a sociedade, no sentido de inclusão, porém excluindo aquilo que não a legitima.

A lei funciona cada vez mais como norma, [...] a instituição judiciária se integra cada vez mais num contínuo de aparelhos (médicos, administrativos etc.) cujas funções são sobretudo reguladoras. Uma sociedade normalizadora é o efeito histórico de uma tecnologia de poder centrada na vida (FOUCAULT, 1988, p. 135).

A luta política, nesse sentido, se dá em razão da possibilidade de vida, muito mais que da possibilidade jurídica. O discurso que se apre- 
senta na categoria "bicha" é a formação liberal de um inimigo, um inimigo sexual, o qual precisa ser exterminado das vistas do espaço que se observa. Essa bipolaridade amigo/inimigo é um jogo político, utilizado na ideologia liberal para que ambas as subjetividades sejam observadas e se observem como antagonistas. Um é a medida do outro, com isso "a ilusão da ordem depende em larga medida de uma simples - mas fundamental - decisão sobre o radicalmente outro" (MATOS, 2012, p. 308).

É aí que a liberdade de manifestação se insere como suspensão do próprio Direito, contraditoriamente, realizando-o. Se "bicha" é expressão de utilidade para a demarcação do sujeito homem, os valores e interesses que a ela se agregam não têm tanta importância, desde que o direito de fala seja manifestado.

O Direito não é negado por essa transposição do limite da liberdade de expressão, mas por ela cristalizado. Não há Direito sem um modelo de efetiva conotação de seu próprio uso por quem lhe demanda. De um lado, o homem exige que "bicha" continue sendo utilizado como forma de expressão no direito de torcer, na cultura torcedora, de outro lado, a demanda que tenta obstaculizar o uso da expressão, utiliza o mesmo Direito. Ou seja, o que parece contradição é justamente a realização do Direito como instrumento de controle e uso da violência, monopólio da ordem jurídica.

\section{ConsideraÇões Finais}

Construção social que é atravessada por vários discursos, a masculinidade se pressupõe como o delineamento do futebol. Em se tratando de um jogo para além do lazer ou da partida profissional, o espaço do futebol determina práticas específicas dentro do seu contexto. O homem no futebol é a representação dupla de si mesmo e do que o jogo representa. Logo, a partida de futebol é um momento político específico, espetáculo de desempenho de papéis.

Dito de outra maneira, o futebol é a representação do homem na sociedade, bem como, a sociedade e seus problemas de gênero são representados no jogo de futebol. Assim, é evidente que as circuns- 
tâncias que permeiam a falta de masculinidade ou "macheza" sejam censuradas.

A expressão não pode ser a do extermínio do locus subjetivo do homossexual, uma vez que ele precisa aparecer e existir para ser afastado. É a medida de normalidade do homem que fornece o papel a ser desempenhado no campo de futebol. O estádio é a representação de tudo o que pode acontecer no controle da sexualidade.

Longe de apontar a sexualidade e julgá-la apenas, a marca do espetáculo futebolístico é a determinação do lugar exato da performance masculina. O que se destaca nesse ponto não é a vida privada do indivíduo, mas aquilo que ele representa com a sua ação corporal durante o jogo. O corpo, nesse sentido, começa a emitir os primeiros discursos de administração sobre a sexualidade.

Uma expressão vem carregada de ideologias, histórias, sociabilidades e uma vasta gama de interações anteriores a sua emissão. Gritar "bicha", portanto, é uma forma de garantir que a homossexualidade esteja posta em espaço determinado, enquadrado. O campo de futebol torna-se irrestrito, atravessado por todas as formas de agir, porém fixado na ação masculina.

O que se observa, então, é que o campo de futebol não se restringe apenas ao espaço concreto do jogo. Ele é apenas uma das eclosões do modelo de sociabilidade ao qual o futebol, já devidamente institucionalizado, cogita o masculino. Dentro do campo de futebol há representações diversas de relações de poder existentes. O estádio de futebol é reflexo da família, da escola, do trabalho, enfim, dos espaços de socialização ao qual o homem transparece como figura central na tarefa de ação.

Isto posto, entende-se que a homossexualidade entra tal espaço de maneira que seja a marcação necessária do desvio de conduta que legitima a ação discursiva. Se o jogo pretende-se masculino, a falta de uma das características supostamente inerentes ao homem deve ser devidamente acionada, para que se processe sua interdição. A exclamação "bicha" reforça esse jogo político que o futebol é apenas mais um dos mecanismos de dominação. 
Para tanto, deve-se levantar um direito de manifestação ancorado em valores liberais, os quais fomentam toda uma rede de poderes que é cruzada pelo que se diz sobre as sexualidades. $\mathrm{O}$ homem, como sujeito participativo do jogo de futebol, produz por meio de um direito de fala a sua marcação espacial e subjetiva.

O Direito determinado nessas relações de poderes é um Direito que visa à conduta normalizadora. Ancorado no lícito e ilícito sobre a ação do homem, o livre direito de manifestação é legitimado para expressar a interdição da subjetividade não masculina. Isso objetiva uma condução da participação política dos homossexuais no espetáculo do futebol.

O Direito liberal é utilizado sempre para garantir legitimações. A mesma ferramenta para questões diametralmente opostas na participação política. Isso faz que a realização de uma suspensão da lei seja a sua própria realização. O Direito que oprime é o mesmo Direito que se utiliza para a supressão dessa opressão.

Reside aí o fato de que se urge por uma entrada de todos (independentemente de gênero ou sexualidade, com base em princípios jurídicos de igualdade, por exemplo) no espaço do jogo de futebol, reforçando a dinamicidade do ser homem: a disputa por quem quer que jogue ainda habita no solo das características do masculino. Por um pensamento jurídico que integre todos, acaba-se reafirmando a posição central do homem. O campo de futebol torna-se um dispositivo de confirmação do homem como a base primordial de ação política.

A mudança que se pretende não pode ser a mera inserção de todos no campo de futebol, mas que o estádio seja um não lugar, isto é, um lugar qualquer, para que as possam, aí sim, nele se inserir sem que para isso haja qualquer centralidade de ação.

\section{REFERÊNCIAS}

AGAMBEN, Giorgio. Homo sacer: o poder soberano e a vida nua. Trad. Henrique Burigo, 2 ed. Belo Horizonte: Editora UFMG, 2010. 
ALABARCES, Pablo; MOREIRA, Maria Veronica; ZUCAL, José Garriga. $\mathrm{El}$ "aguante" y las hinchadas argentinas: una relación violenta. In: Horiontes Antropológicos, Porto Alegre, a. 14, n. 30, jul./dez. 2008, p. 113-136.

BUTLER, Judith. Excitable speech: a politics of the performative. New York/London: Routledge, 1997.

CECCHETTO, Fátima Regina. Violência e estilos de masculinidade: violência, cultura e poder. Rio de Janeiro: FGV, 2004.

CONNELL, R. W. Masculinities and globalization. In: AGGLETON, Peter; PARKER, Richard. Culture, society and sexuality. New York: Routledge, 2007.

ELIAS, Norbert; DUNNING, Eric. A Busca da Excitação. Lisboa: Difel, 1992.

FOUCAULT, Michel. A arqueologia do saber, 7. ed. Rio de Janeiro: Forense Universitária, 2008.

. A ordem do discurso. São Paulo: Loyola, 1996.

. As palavras e as coisas: uma arqueologia das ciências humanas.

Trad. Salma Tannus Muchail, 8. ed. São Paulo: Martins Fontes, 1999.

. On the Genealogy of Ethics: An Overview of Work in Progress. In: DREYFUS, Hubert; RABINOW, Paul. Michel Foucault: Beyond Structuralism· and Hermeneutics. Chicago: The University of Chicago Press, p. 238-243.

FREITAS, Riva Sobrado; DE CASTRO, Matheus Felipe. Liberdade de Expressão e Discurso do Ódio: um exame sobre as possíveis limitações à liberdade de expressão. In: Seqüência: Estudos Jurídicos e Políticos, Florianópolis, p. 327-355, jul. 2013. ISSN 2177-7055. Disponível em: https://periodicos. ufsc.br/index.php/sequencia/article/view/2177-7055.2013v34n66p327. Acesso em: 15 out. 2016.

GASTALDO, Édison. "O complô da torcida": futebol e performance masculina em bares. In: Horizontes Antropológicos. Porto Alegre, a. 11, n. 24, jul./ dez. 2005, p. 107-123.

GOFFMAN, Erving. Comportamento em lugares públicos. Trad. Fábio Rodrigues Ribeiro da Silva. Petrópolis, RJ: Vozes, 2010. 
GUEDES, Simoni Lahud. Subúrbio: Celeiro de Craques. In: DA MATTA, Roberto (Org.). Universo do Futebol: esporte e sociedade Brasileira. Rio de Janeiro: Pinakotheke, 1982, p. 59-72.

HALL, Stuart. Da Diáspora: identidades e mediações culturais. Trad. Adelaine La Guardia Resende. Liv Sovik (Org.). Belo Horizonte: Editora UFMG. Brasília: Representação da UNESCO no Brasil, 2003.

LACLAU, Ernst. La razón populista. Buenos Aires: FCE, 2005.

MATOS, Andityas Soares de Moura Costa. NÓMOS PANTOKRÁTOR? apocalipse, exceção, violência. In: Revista Brasileira de Estudos Políticos, ${ }^{\circ}$. 105, Belo Horizonte: Programa de Pós-Graduação da Faculdade de Direito da Universidade Federal de Minas Gerais, jul./dez. 2012, p. 277-342.

MOTT, Luiz. Violação dos direitos humanos e assassinato de homossexuais no Brasil. Salvador: Grupo Gay da Bahia, 2000.

PONS, Juan Carlos Cabrera. Puto: normalización institucional de la discriminación em el fútbol. In: Desbordes - Revista de investigaciones de la Escuela de Ciencias Sociales - UNABD - v. 5, ene./dec. - 2014, p. 75-82. Disponível em: http://hemeroteca.unad.edu.co/index.php/desbordes/article/ download/1308/1644. Acesso em 3 mar. 2017.

PRADO, Marco Aurélio Máximo; MACHADO, Frederico Viana. Preconceito contra homossexualidades: a hierarquia da invisibilidade. São Paulo: Cortez, 2012.

SAMPAIO, Nadja. O Esporte na Televisão. In: DIEGUEZ, Gilda Korff (Org.). Esporte e Poder. Petrópolis, RJ: Vozes, 1985.

SEGATO, Rita Laura. Las estructuras elementales de la violencia. Ensayos sobre género entre la antropología, el psicoanálisis y los derechos humanos. Bernal: Universidad de Quilmes, 2003.

SOARES, Antônio Jorge. História e Invenção de Tradições no Campo do Futebol. In: Estudos Históricos, n. 23. Rio de Janeiro, CPDOC FGV, 1999, p. 119-146.

SOUZA, Marcos Alves de. Gênero e raça: a nação construída pelo futebol brasileiro. In: Cadernos Pagu, v. 6, n. 7, 1996, p. 109-152. 
VANEIGEM, Raoul. A arte de viver para as novas gerações. São Paulo: Veneta, 2016.

WALDRON, Jeremy. Dignity and defamation: the visibility of hate. In: Oliver Wendell Holmes Lectures, Havard Law Review. v. 123, 2010, p. 1597-1657. Disponível em www.law.nyu.edu/sites/default/files/ECM_PRO_063312.pdf. Acesso em 30 mai. 2016.

WODAK, Ruth. De qué trata el análisis crítico del discurso (ACD). Resumen de su historia, sus conceptos fundamentales y sus desarrollos. In: WODAK, Ruth; MEYER, Michael. (comps.). Métodos de análisis crítico del discurso. Barcelona: Gedisa, 2003, p. 17-34.

\section{SOBRE O AUTOR}

João Carlos da Cunha Moura

Mestre em Direito e Instituições do Sistema de Justiça pela Universidade Federal do Maranhão. Professor do curso de Direito da Unidade de Ensino Superior Dom Bosco (UNDB). Servidor do Tribunal de Justiça do Estado do Maranhão. Professor na Faculdade Laboro.

CV: http://lattes.cnpq.br/9237512857575587

E-mail: jc_yupe@hotmail.com

Submetido em: 05-07-2017

Aceito em: 16-10-2017 